\title{
Research on the Innovation of Teaching Management Mode in Private Independent Colleges
}

\author{
Hui Zhang ${ }^{1, a}$, Fang Wang ${ }^{1, b}$, Guan Wang ${ }^{1, c}$
}

${ }^{1}$ Jincheng College of Nanjing University of Aeronautics and Astronautics, Nanjing, Jiangsu, 211156

${ }^{\mathrm{a}}$ email, ${ }^{\mathrm{b}}$ email, ${ }^{\mathrm{c}}$ email

Keywords: Private Independent Colleges, Teaching Management, Innovation Research

\begin{abstract}
At present, the innovative education aiming at cultivating students' innovative spirit and autonomous learning ability has put forward a series of reform requirements for the existing educational ideas, management system, operation mechanism and teaching methods for imparting existing knowledge. This determines the private independent institutions must promptly change the mode of personnel training, change and innovation teaching management, to adapt to the full promotion of quality education, training creative talent needs. Teaching management as a private independent institutions are to manage the basic activities and the central link in the school has an important position and role, it is the basis for the normal operation of teaching activities, but also to improve the quality of teaching an important guarantee. At present, the teaching management of higher vocational colleges is in a progressive stage of development.
\end{abstract}

\section{Introduction}

In recent years, with the transformation of higher education from "elite education" to "popular education", higher education has achieved leapfrog development, private independent institutions contributed to the contribution. As of the end of 2009, China's higher vocational colleges have 1215, more than 1090 undergraduate colleges, higher vocational (specialist) full-time students in the average size of 9086 people. 1 and the basic formation of each city (land) at least set up a private independent institutions of the pattern, with local economic and social development and the interests of the people the most direct and most closely related institutions of higher education. It can be said that private independent institutions in China's higher education scale has accounted for "half of the country", has become an important part of China's higher education. The rapid growth of the number of students in private colleges and universities has provided new opportunities for the development of higher education in our country, but also brought greater pressure to the teaching and personnel training of higher vocational education. Different from the ordinary higher education institutions to cultivate research talents as the goal, private independent institutions in the personnel training objectives are more focused on the actual needs of society, training advanced technology applied talents. At present, the innovative education aiming at cultivating students' innovative spirit and autonomous learning ability has put forward a series of reform requirements for the existing educational ideas, management system, operation mechanism and teaching methods for imparting existing knowledge. This determines the private independent institutions must promptly change the mode of personnel training, change and innovation teaching management, to adapt to the full promotion of quality education, training creative talent needs.

\section{The Content of Teaching Management in Private Colleges}

Teaching plan is an important document to ensure the quality of teaching and personnel training. It is the basic basis for organizing teaching activities, arranging teaching tasks and ensuring teaching preparation. Teaching plan is under the guidance of the Ministry of Education under the auspices of the state, organized by the various experts to develop their own, it is necessary to meet the law of education, to maintain a certain degree of stability, but also according to social, economic, scientific and technological development in a timely manner to adjust And revision. Private independent college teaching plan is developed by professional and is to ensure the quality of teaching the basic 
teaching documents. The core work of the teaching plan management is to design a blueprint for the cultivation of talents, which requires us to devote a great deal of energy to the necessary and necessary basic investigation and research. This research includes the reform and development of the same and similar disciplines at home and abroad, especially the new educational concept, the new teaching content and curriculum system, teaching links and personnel training mode and so on. To organize the academic disciplines of academic disciplines and experienced teachers in the first study of the curriculum structure system, only the design and construction of a whole structure of the curriculum system optimization, the overall design of the blueprint for personnel training clearly, to be able to cultivate High quality qualified graduates. Of course, the teaching plan in the development of a firm organization after the implementation of the teaching plan is not only a blueprint for design can be arbitrary. Its content and requirements reflect the characteristics of personnel training specifications and models. Private colleges and universities in the organization of teaching plans focus on the curriculum system is the establishment and reform, curriculum reform should pay attention.

Teaching management is mainly around the implementation of the teaching plan carried out by the teaching process and related auxiliary work organization and management. Its purpose is to organize the implementation of teaching plans and to ensure the normal operation of school teaching. Teaching process is essentially a student under the guidance of a teacher in the process of understanding, but also students through the teaching of a comprehensive development of a unified process. Teaching operation and management of the key is to do the following two aspects: First, classroom teaching (including theoretical teaching and practical teaching) management; Second, the daily teaching administration, that is, educational administration. Higher vocational teaching operation and management should pay attention to: in the classroom teaching, different levels (education level, skills level) of the educational object of teaching organization and implementation, focusing on clever use of teaching methods; class, class, exam and other teaching links running coherence, Improve the credit system; mobilize all available resources, organize internal and external practice teaching, flexible operation performance assessment methods. In the educational administration, educational administration mainly refers to the school, secondary college, teaching department (campus) and other teaching management departments should be based on teaching rules and school rules and regulations to exercise management authority, the teaching activities and related auxiliary work scientific and reasonable Of the organization, command, scheduling, to ensure the school teaching work in a stable and orderly manner of coordination process, of course, including strict norms to do a good job teaching daily management, student management and teaching file management. Merged and upgraded vocational colleges more serious teaching management, such as the need to ensure that before the merger of the school teaching materials, student files archives unified archives, so no omission and the establishment of a complete system.

\section{The Main Connotation of Teaching Management Reform and Innovation in Private Colleges}

The reform and innovation of teaching management in private independent colleges must first be based on the idea of changing education and establishing the concept of modern education as the forerunner and impetus. The modernity of private independent institutions is mainly reflected in the conditions of running schools, school management, quality of education, quality of personnel, etc., of which management is the key. The "scientific development concept" proposed by the state is the development concept of the subject and the object, the unity of man and nature, and the unity of quality and quantity of development. Emphasis on the all-round development, harmonious development and multidimensional development; The scientific concept of development provides a strong theoretical basis for the reform of education and teaching management, which is of great significance to the reform and development of higher vocational education. The transformation of educational ideas is a process, to make the teaching management from the past "experience" to "scientific", managers must maintain the educational ideas of the ever-changing and timely updates. To learn the concept of science, advanced management concepts; master certain management knowledge, such as educational administration, higher education management; to establish the 
system concept, talent concept, information concept, efficiency concept; from the teacher and student point of view Problems, to provide them with personalized service, advocated by the management of the work to the service-oriented change. The new teaching management concept to highlight the "people-oriented" is the management and education of the close integration, to achieve quality and win-win goal.

In order to speed up the substantive integration of the individual organizations and promote the leap-forward development of the schools, it is necessary to carry out comprehensive reform and innovation of the teaching management system in order to realize the goal of building distinctive characteristics. At present, there are four kinds of basic management modes existing in the university, namely, the three-level management mode of the school and the hospital. Combined with the scale and characteristics of private independent institutions, we must first establish a suitable management system model for the development of the school, and then from the perspective of discipline development, personnel training, management innovation, school efficiency perspective, and gradually promote the overall reform of the teaching system. Teaching management rules and regulations is the teaching and learning philosophy, teaching management guiding ideology and habitual management of the form of expression.

Sound rules and regulations, in line with the inherent requirements of education and management science, is conducive to the establishment of standardized teaching order, is conducive to mobilize teaching, learning, management and other aspects of enthusiasm, is conducive to advancing teaching reform, is conducive to improving the quality of personnel training. Establish and improve the teaching management of the rules and regulations, the development of the various teaching aspects of the standard requirements, so that the school teaching management rules to follow, according to the law, the strict management throughout the entire process of personnel training.

The teaching management system of multi-layer ring, interlocking, close structure and function optimization is constructed. Through the system "loop, cycle", we should pay attention to the design, inspection, monitoring, evaluation and feedback function of education and teaching management Management of the quality of teaching monitoring, protection and guidance of student learning function, and strengthen the teaching evaluation in the teaching management of the incentive, guiding role. According to the functional requirements of teaching management, according to the point of view of cybernetics, this teaching management system should include four subsystems, such as teaching decision-making, execution, monitoring, communication and feedback.

The teaching activities of colleges and universities are a kind of intellectual high-level activities. At the same time, the participants, teachers and students of teaching activities have higher quality. Therefore, the teaching management can not always be strict, but should be used in strict management Incentive mechanism to mobilize the enthusiasm and consciousness of teachers and students. To improve and improve the effectiveness of teaching evaluation system, excellent teaching (including practical teaching) reward system, etc., to encourage teachers to actively teach and make greater achievements in teaching; to establish a good student reward system, scholarship system, personal expertise (including Design, production, invention, creation, etc.) incentive system, to stimulate students 'potential enthusiasm for learning, training students' innovative consciousness and innovative spirit. This is from the heart of the teaching and learning generated spontaneous power, fundamentally improves the quality and efficiency of teaching management.

The teaching model is a specific combination of curriculum view, curriculum content, curriculum structure and its evaluation system, that is, the teaching mode is guided by a certain curriculum, curriculum content and its process and arrangement in time and space in a specific combination of ways. Social and economic development, especially the progress of technology, the application of talent specifications change, will lead to changes in teaching mode. The traditional teaching model has been gradually replaced by the information age teaching model, from the "traditional teaching mode and information age teaching mode comparison table", we can easily find the main body of learning, teaching methods, teachers and many other aspects of the role of change. 


\section{Conclusion}

The reform of teaching management in private independent colleges is a close combination of theory and practice. Both the need for theoretical innovation, but also have a strong system and practical. As many private independent institutions have been established in recent years, teaching management mechanism is very imperfect. Is basically copy the copy of undergraduate teaching management model. Teaching Management needs urgently reform and innovation. I have been working in the school's teaching management office for many years, although every day facing a tedious work, but deeply teaching management responsibility: how to really improve the quality of teaching management, how to change the status of teaching management, how the scientific The introduction of educational ideas to enhance the level of teaching management, and how to achieve the teaching management process of innovation and so on such issues cause my interest. It Is based on this, as a topic of my thesis. In the course of this research, I deeply feel that teaching management is a very complex integrated system. The reform of teaching management should closely focus on the reform of personnel training mode. And school teaching reform, and leadership system, personnel system and so on. The research content is very rich, involving a wide range of work is very large, at the same time, teaching management practice is strong, and the school discipline professional characteristics and their own tradition is a strong correlation, research and practice closely, to have a strong Targeted and operable.

\section{References}

[1] Chen Bin. Reflections on the innovation of teaching management in higher vocational colleges [J] .Chinese Journal of Adult Education, 2010 (09)

[2] Dai Shiying. The reform and innovation of teaching management in colleges and universities [J]. Theoretic circles, 2010 (05)

[3] Guo Huicong. New era of university teaching management innovation [J]. Taiyuan City Vocational and Technical College, 2010 (04)

[4] Yang Xiaoning. Some Thoughts on the Innovation of Teaching Management in Chinese Universities [J]. Journal of Shaanxi Radio \& TV University, 2010 (01)

[5] Li Xiuqin. Higher vocational college innovation teaching management research [J]. Science and Technology Forum (the second half), 2009 (12)

[6] Wu Wei, Gong Qian, Lu Xiaoxuan, Wan Jian. Teaching management innovation in higher vocational colleges thinking [J]. Hubei Adult Education Institute, 2009 (05) 